\title{
E-partycypacja i ISO 37120 jako wyznacznik implementacji rozwoju zrównoważonego w smart city
}

\author{
E-Participation and ISO 37120 as a Reference for the Implementation \\ of Sustainable Development in a Smart City
}

\author{
Paulina Legutko-Kobus \\ Kolegium Ekonomiczno-Społeczne, Szkoła Główna Handlowa w Warszawie \\ ORCID: https://orcid.org/0000-0003-0380-8913•paulina.legutko-kobus@sgh.waw.pl \\ Zgłoszono: 13.01.2020; zrecenzowano: 27.02.2021; zaakceptowano do druku: 4.03.2021
}

\begin{abstract}
Streszczenie: Smart city to miasta, w których kwestie publiczne rozwiązywane są z wykorzystaniem technologii informacyjnych i komunikacyjnych (ang. ICT). Od początku rozwoju tej koncepcji (lata 90. XX w.) zakładano, że miasto inteligentne to równocześnie miasto dążące do wdrożenia rozwoju zrównoważonego. Artykuł koncentruje się na następujących aspektach badawczych: jak definiowane i klasyfikowane są smart city; które polskie miasta ujmowane są w międzynarodowych rankingach smart city; jak koncepcja smart city może przyczyniać się do wdrażania rozwoju zrównoważonego. Polskie miasta nie należą do liderów smart city w skali międzynarodowej. Wiele z nich implementuje jednak elementy koncepcji 3.0, wykorzystując idee smart do wdrażania rozwoju zrównoważonego. Poszczególne wymiary smart city (w literaturze wskazuje się ich 6) odnoszą się do aspektów rozwoju zrównoważonego i pozwalają osiągać ład zintegrowany. Norma ISO 37120 jest z jednej strony certyfikatem wdrożenia idei smart, z drugiej zaś stosowana jest jako instrument oceny poziomu wdrożenia rozwoju zrównoważonego. Miasta, które w Polsce certyfikowane są według tej normy, to: Gdynia, Gdańsk, Kielce, Lublin i Warszawa. Artykuł wskazuje, że wdrażanie koncepcji smart city może przyczyniać się do szybszego i skuteczniejszego osiągnięcia rozwoju zrównoważanego na obszarach miast nie tylko dzięki coraz doskonalszym technologiom, lecz przede wszystkim dzięki zwiększeniu zaangażowania społecznego (wykorzystującego narzędzia e-partycypacji do współdecydowania) oraz dążeniu miast do pozyskiwania i udostępniania coraz lepszych i dokładniejszych danych związanych z różnymi aspektami rozwoju zrównoważonego.
\end{abstract}

Słowa kluczowe: smart city, rozwój zrównoważony, e-partycypacja, ISO 37120

\begin{abstract}
Smart cities approach and handle public matters, using information and communication technologies (ICT). Since the concept surfaced in the 1990s, a smart city has been regarded as one seeking to embody the principle of sustainable development. The article focuses on the following research questions: How are smart cities defined and classified? Which Polish cities have made it to the global smart city rankings? How can the smart city concept contribute to the implementation of sustainable development? Polish cities are not ranked among the smart city leaders, globally. However, many of them put some elements of the Smart City 3.0 concept into use, thus, applying the "smart" ideas for sustainable development implementation. The smart city dimensions (up to six are named in the publications on the subject) refer to some aspects of sustainable development, while allowing the achievement of integrated governance. On one hand, the ISO 37120 standard is a certificate of implementation of the smart concept; but, on the other hand, it is used as a reference for assessment of the level of sustainable development implementation. Polish cities certified, according to this standard, are: Gdynia, Gdańsk, Kielce, Lublin, and Warsaw. The article highlights that the implementation of the smart city concept
\end{abstract}


is very likely to contribute to the faster and more effective achievement of sustainable development in urban areas. This can be done, not only through a greater use of high-end technologies but, above all, through civic involvement (by employing e-participation tools for co-determination purposes) and cities' aspirations to collect and share better quality and more accurate data, on various aspects of sustainable development.

Keywords: smart city, sustainable development, e-participation, ISO 37120

\section{Wprowadzenie}

Smart city definiuje się w różny sposób, ale we wszystkich podejściach teoretycznych podkreśla się, że są to miasta wykorzystujące technologie informacyjne i komunikacyjne w rozwiązywaniu problemów rozwojowych, publicznych. Za smart uznajemy miasto, które równocześnie inwestuje w kapitał ludzki i społeczny oraz w nowoczesną infrastrukturę ICT i e-usługi. Celem tych inwestycji jest osiągnięcie rozwoju zrównoważonego, rozumianego jako zagwarantowanie wysokiej jakości życia dzięki pełnemu wdrożeniu zasad zarządzania partycypacyjnego i odpowiedzialnego gospodarowania zasobami (Caragliu et al. 2011). Miasta te kładą nacisk na: rozwój infrastruktury związanej z technologią i informatyką, cyfryzację i otwieranie zasobów miejskich, a równocześnie są to miasta wdrażające innowacje oraz zarządzanie partycypacyjne (dlatego nastawione są na dialog $\mathrm{z}$ interesariuszami i angażowanie różnych ich grup z wykorzystaniem technologii cyfrowych). Drugie ujęcie, tj. rozumienie smart city jako miasta ekologicznego, kładzie nacisk na wykorzystywanie technologii do poprawy jakości środowiska przyrodniczego i zapewnienia wysokiej jakości życia.

Wychodząc z tych przesłanek, artykuł koncentruje się na poszukiwaniu odpowiedzi na następujące pytania badawcze:

- jak definiowane i klasyfikowane są smart city;

- które polskie miasta znajdują się w rankingach smart;

- jak koncepcja smart city przekłada się na możliwość wdrażania rozwoju zrównoważonego (szczególnie w oparciu o normę ISO 37120 i szeroką e-partycypację).

Tak sformułowane pytania badawcze zdeterminowały układ tekstu oraz zastosowane metody badawcze. Ze względu na specyfikę tematyki zastosowane zostały metody: krytyczna analiza literatury przedmiotu oraz analiza materiałów źródłowych pozyskanych z oficjalnych portali internetowych urzędów miast (szczególnie związanych z implementacją smart city: rankingami, podejmowanymi działaniami w konkretnych miastach oraz certyfikacjami).

\section{Ewolucja podejścia do smart city}

Biorąc pod uwagę problematykę niniejszego artykułu, szczególnie istotne jest wskazanie powiazań między smart city a miastem wdrażającym zasady rozwoju zrównoważonego. Zdaniem Borysa (2011, 77) konkretyzacja koncepcji rozwoju zrównoważonego opiera się na zasadach: trwałości, równoważenia, samopodtrzymywania/ sustensywności. Papuziński (2014, 13-14) wskazuje ponadto na zasadę sprawiedliwości międzygeneracyjnej jako konstytuującą rozwój zrównoważony. Przenosząc te zasady na grunt funkcjonowania miast, smart city zdefiniować możemy jako zarządzanie przestrzenią publiczną prowadzące do rozwiązywania problemów społecznych i środowiskowych w miastach (Hajduk 2020, 125).

Należy podkreślić, iż od początku rozwoju koncepcji smart city zakładano, że miasto inteligentne to równocześnie miasto dążące do wdrożenia rozwoju zrównoważonego, a w literaturze przedmiotu funkcjonują dwa pojęcia pokrewne dotyczące tych kwestii, tj. eco-cities i green cities. 
Eco-cities rozumiane jest jako miasto zapewniające wysoką jakość życia, w którym stawia się na pozyskanie energii z odnawialnych źródeł, a komunikacja oparta jest na wysokiej jakości transporcie publicznym oraz zapewnieniu dobrze rozwiniętej infrastruktury rowerowej (Węcławowicz-Bilska 2012, 324-325). W tym podejściu stosowanie technologii pomaga: zniwelować niekorzystny wpływ na środowisko (np. zanieczyszczenia powietrza), zmniejszyć strumień powstających odpadów i ich odziaływanie na środowisko, zmniejszyć terenochłonność, zapewnić wysoką jakość wody pitnej, umożliwić wszystkim mieszkańcom dostęp do wysokiej jakości terenów zieleni oraz ograniczać zużycie energii. Do europejskich miast liderów eco-cites można zaliczyć: Rejkiawik, Zurich, Bristol, Malmö, Sztokholm, Kopenhagę i Oslo (Betterworldsolutions.eu 2020).

W Polsce od 2013 r. organizowany jest plebiscyt (konkurs) ECO-MIASTO. Obecna 7. edycja dotyczy pięciu kategorii: gospodarka wodna, zieleń miejska, gospodarka odpadami, zrównoważona mobilność oraz efektywność energetyczna. W poprzedniej edycji konkursu (2018) laureatami były: w kategorii mobilność zrównoważona: Lublin i Niepołomice $^{1}$; w kategorii efektywność energetyczna budynków: Kraków i Czeladź; w kategorii gospodarka wodna: Lublin i Mława; w kategorii gospodarka o obiegu zamkniętym: Białystok i Radzyń Podlaski; w kategorii zieleń a powietrze: Zabrze i Złotów (Eco-miasto.pl 2020).

Idea green cities zakłada uwzględnianie społecznych i technologicznych aspektów zielonego wzrostu gospodarczego oraz zazieleniania planowania przestrzennego (Berreta 2018). Rankingi „zielonych miast” dotyczą przede wszystkim terenów zieleni przypadających na 1 mieszkańca. W rankingach światowych stolic w tym zakresie dobrze wypada Warszawa (109 $\mathrm{m}^{2}$ zieleni

\footnotetext{
1 Ideą konkursu jest nagradzanie miasta dużego powyżej 100 tys. mieszkańców oraz miasta mniejszego niż 100 tys. mieszkańców, dlatego podawani są dwaj laureaci w każdej z kategorii.
}

na jednego mieszkańca, czyli 10 razy więcej niż np. Paryż, ale do zwycięzcy rankingu, czyli Rejkiawiku z $410 \mathrm{~m}^{2}$ zieleni na jednego mieszkańca, Warszawie jeszcze daleko) (Gazeta.pl 2018). Jak podkreśla się w literaturze, miasta zielone to przede wszystkim miasta zwarte, zapobiegające „rozlewaniu się” poprzez racjonalne kształtowanie struktur przestrzennych, w tym zieleni miejskiej (Hulicka 2015, 74-75).

Literatura przedmiotu posługuje się także pojęciem sustainable city $^{2}$, a nawet łączy je bezpośrednio ze smart city (idea smart sustainable cities), w których wykorzystanie nowoczesnych technologii umożliwia zaspokajanie potrzeb współczesnych mieszkańców miast, bez pomniejszania szans rozwojowych przyszłych pokoleń (Höjer and Wangel 2014).

Współczesne miasta inteligentne, wdrażając do polityki lokalnej zasady rozwoju zrównoważonego, stawiają także na zasady ekonomii współdzielenia (np. poprzez sieci wypożyczalni rowerów miejskich, hulajnóg czy elektrycznych bądź hybrydowych samochodów na minuty) oraz partycypacyjne planowanie przestrzeni miejskiej, w tym szczególnie przestrzeni publicznych i terenów zieleni. Zdaniem niektórych badaczy to właśnie smart city stanowią szczególne środowisko (habitat) do rozwoju przejawów ekonomii współdzielenia (Gori et al. 2015, 5). Z wdrażaniem idei smart można także powiązać gospodarkę o obiegu zamkniętym, stanowiącą jeden ze współczesnych przejawów wdrażania rozwoju zrównoważonego (Sobol 2017, 84).

2 Pojęcie „zrównoważone miasto” popularyzowane jest przez Kongres i Kartę Nowej Urbanistyki i w tym ujęciu dotyczy przede wszystkim projektowania przestrzeni miejskich zakładającego szeroką partycypację społeczną i prowadzącego do osiągnięcia ładu przestrzennego, rewaloryzacji centrów miast czy rewitalizacji obszarów zdegradowanych. Równocześnie należy podkreślić wieloznaczność i próby systematyzowania tego pojęcia, które podejmuje literatura przedmiotu (Lewandowska 2014; Sobol 2017). 
Wymiary smart city mogą być wdrażane zarówno kompleksowo do wszystkich elementów zarządzania miastem, jak i punktowo do poszczególnych obszarów tematycznych/zarządczych. Literatura przedmiotu wyróżnia 6 wymiarów smart city, które można wpisać w poszczególne elementy (składowe) tadu zintegrowanego ${ }^{3}$ (tabela 1).

3 Ład zintegrowany - docelowy stan, który powinien zostać osiągnięty we wdrażaniu rozwoju zrównoważonego (rozumianego jako proces). Ład zintegrowany zakłada więc tworzenie spójnych, niesprzecznych celów obejmujących ład: społeczny, polityczno-instytucjonalny, ekonomiczny (gospodarczy), środowiskowy i przestrzenny (Borys 2011, 77-78).
Na przestrzeni lat w podejściu do smart city można wskazać ewolucję (kolejne generacje miast inteligentnych), od smart city 1.0 do smart city 3.0 (Cohen 2015). Koncepcja smart city 1.0 dotyczy tych miast, które wdrażają rozwiązania technologiczne do usprawnienia zarządzania urzędem i miastem, w tym innowacyjne platformy do komunikacji oraz do usprawniania procesów administracyjnych.

Smart city 2.0 to bardziej zaawansowana forma miast inteligentnych, gdzie celem wdrażania innowacji jest szeroko rozumiana poprawa jakości życia mieszkańców. W tym podejściu technologia i czynnik ludzki są równie ważne. Miasta zaliczane do drugiej generacji smart cities realizują projekty,

Tabela 1. Wymiary smart city w kontekście ładów budujących ład zintegrowany

\begin{tabular}{|c|c|c|c|}
\hline Wymiar smart city & Krótka charakterystyka & $\begin{array}{l}\text { Odniesienie do } \\
\text { ładów rozwoju } \\
\text { zrównoważonego }\end{array}$ & \\
\hline Smart people & $\begin{array}{l}\text { użytkownicy miasta postrzegani są jako inicjatorzy zmian; to } \\
\text { podejście obejmuje wszystkie rodzaje innowacji wpływających } \\
\text { na poprawę jakości życia oraz podejmowanie współpracy } \\
\text { między różnymi interesariuszami. Rozwój kapitału społecznego, } \\
\text { prowadzenie działań promujących mechanizmy samouczenia się }\end{array}$ & społeczny & \multirow{6}{*}{ 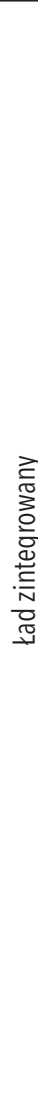 } \\
\hline Smart living & $\begin{array}{l}\text { miasta - dobre miejsce do życia, oferujące wysoką jakość usług } \\
\text { publicznych, dostęp do infrastruktury oraz wysoki poziom } \\
\text { bezpieczeństwa i dobrą jakość środowiska przyrodniczego. } \\
\text { Wykorzystanie rozwiązań informatycznych w takich obszarach, jak: } \\
\text { działalność socjalna, ochrona zdrowia, czy funkcjonowanie urzędów }\end{array}$ & $\begin{array}{l}\text { społeczny, polityczno- } \\
\text { instytucjonalny, } \\
\text { środowiskowy }\end{array}$ & \\
\hline Smart environment & $\begin{array}{l}\text { racjonalne wykorzystanie zasobów zgodnie z zasadą rozwoju } \\
\text { zrównoważonego, wykorzystanie źródeł energii odnawialnej, } \\
\text { zmniejszenie emisji zanieczyszczeń do środowiska, wdrażanie } \\
\text { ekoinnowacji, działania proekologiczne. Monitoring i zarządzanie } \\
\text { mediami, takimi jak energia, woda, gaz }\end{array}$ & $\begin{array}{l}\text { środowiskowy, } \\
\text { przestrzenny }\end{array}$ & \\
\hline Smart governance & $\begin{array}{l}\text { opracowanie i wdrażanie procedur współdziałania interesariuszy, } \\
\text { wykorzystanie technologii w procesach zarządzania miastem, } \\
\text { innowacje organizacyjne i społeczne. Inteligentne sprawowanie } \\
\text { władzy, korzystanie z potencjału interesariuszy (otwarte dane } \\
\text { oraz pełne wdrożenie governance, czyli współdecydowanie, } \\
\text { współdziałanie, współodpowiedzialność) }\end{array}$ & $\begin{array}{l}\text { społeczny, polityczno- } \\
\text { instytucjonalny }\end{array}$ & \\
\hline Smart economy & $\begin{array}{l}\text { elastyczny rynek pracy, innowacyjność, transfer technologii } \\
\text { z ośrodków akademickich do rozwiązań gospodarczych. Wdrażanie } \\
\text { green economy jako przeciwieństwa brown economy. Gospodarka } \\
\text { wiedzy, odejście od konkurencji na rzecz koopetycji }\end{array}$ & $\begin{array}{l}\text { ekonomiczny } \\
\text { (gospodarczy) }\end{array}$ & \\
\hline Smart mobility & $\begin{array}{l}\text { transport i komunikacja (oraz szerzej mobilność) nastawiona na } \\
\text { dobrze zarządzaną komunikację publiczną i transport niskoemisyjny. } \\
\text { Bezprzewodowe transfery zbiorów informacji oraz zdalny monitoring }\end{array}$ & $\begin{array}{l}\text { środowiskowy, } \\
\text { przestrzenny }\end{array}$ & \\
\hline
\end{tabular}


które służą wdrażaniu nowoczesnych technologii do różnych obszarów życia miasta, np. publiczne sieci WI-FI, zrównoważona mobilność, czujniki np. jakości powietrza, czy inteligentne sterowanie oświetleniem miejskim.

Najbardziej zaawansowana forma wdrażania smart city to generacja miast 3.0 (koncepcja ta wykrystalizowała się w 2015 r.). Podstawowym założeniem funkcjonowania tych miast, nazywanych także miastami obywatelskimi, jest umożliwianie i promowanie aktywnej partycypacji mieszkańców (i innych użytkowników miasta) w planowaniu i wdrażaniu polityki rozwoju. W tym podejściu miasta są współtworzone przez mieszkańców, a rolą władz jest udostępnianie możliwie szerokiej informacji i danych dla mieszkańców (przykładowo tzw. open data, czyli ogólnodostępne dane i statystyki dotyczące miasta) oraz zapewnienie infrastruktury umożliwiającej konsultacje i wspólne podejmowanie decyzji (Dominiak 2016). Pionierami i liderami smart city 3.o są: Wiedeń, Vancouver, Seul, Barcelona i Amsterdam (Dominiak 2020).

Miasta zaliczane do generacji 3.0 określane są także jako Human Smart Cities. To miasta wykorzystujące potencjał ludzki i technologiczny do implementowania rozwoju zrównoważonego, w których technologia działa dla ludzi. Charakteryzują je następujące cechy (MIiR 2019, 5-7):

- użytkownicy miasta są współdecydentami, a miasto działa transparentnie, udostępniając informacje i włączając obywateli w zarządzanie;

- użytkownicy miasta to nie tylko mieszkańcy, lecz także interesariusze zewnętrzni, np. inwestorzy czy turyści. Wszyscy użytkownicy są priorytetem działania miasta, a udostępniane dla nich dane powinny być profilowane;

- miasta wykorzystują potencjał współpracy różnych interesariuszy. Rolą władz miasta jest więc tworzenie warunków (umożliwianie) współpracy międzysektorowej (np. biznesu, nauki, organizacji społecznych);
- nowoczesne technologie wspomagają zarządzanie miastem, w tym szczególnie procedury zarządzania partycypacyjnego - ich wykorzystanie zwiększa zasięg i różnorodność tematów, które mogą współtworzyć użytkownicy, oraz problemów rozwojowych miasta, o których mogą oni współdecydować;

- przyszłość miasta określana w wizji rozwoju odnosi się do rozwoju zrównoważonego z uwzględnieniem zasady sprawiedliwości wewnątrz- i międzygeneracyjnej. Każdy etap określania lokalnej polityki rozwoju zakłada szeroką partycypację (w tym z wykorzystaniem narzędzi e-partycypacji).

\section{Polskie miasta jako smart city}

Z rozważań zaprezentowanych we wcześniejszej części tekstu wynika, że smart city może być różnie definiowane, co oznacza, że poszukując odpowiedzi na pytanie, które polskie miasta zasługują na miano smart (lub próbują do tego tytułu pretendować), można posłużyć się różnymi kryteriach. W niniejszym opracowaniu przyjęto następujące:

- obecność (ujęcie) w międzynarodowych rankingach smart city;

- uznanie za najbardziej innowacyjne miasto w Polsce;

- znalezienie się w gronie laureatów konkursu „Human Smart Cities. Inteligentne miasta współtworzone przez mieszkańców";

- certyfikacja według normy ISO 37120. Ujęcie w międzynarodowych rankingach smart city - polskich miast próżno szukać wśród liderów w tym zakresie, a szczególnie słabo reprezentowane są $\mathrm{w}$ rankingach o zasięgu globalnym. W raporcie przygotowywanym przez Business School University of Navarra "Cities in Motion Index 2019" (IESE.edu 2019) wśród 174 miast znalazły się dwa z Polski, tj. Warszawa na 69. miejscu (w 2018 r. na 54. miejscu) i Wrocław na pozycji 95. (tak jak przed rokiem). Ranking wygrał Londyn przed Nowym Jorkiem oraz Amsterdamem. Warszawa najwyższe noty 
uzyskała w zakresie: planowania miejskiego oraz mobilności i transportu, a najniższe w kategorii technologie i środowisko. Wrocław najwyższe noty uzyskał w tych samych kategoriach, a najniższe w kategorii technologia oraz powiązania międzynarodowe. W rankingu Top 50 Smart City Government (edycja 2018/19) nie znalazło się żadne polskie miasto. Natomiast zwycięzcami rankingu były: Londyn, Singapur i Seul (Eden Strategy Institute and ONG\&ONG Pte Ltd. $2018)^{4}$. Nieco lepiej polskie miasta wypadaja w rankingu opracowanym przez Politechnikę w Wiedniu obejmującym „European Smart Cities”. Tu wśród 70 umieszczonych w rankingu miast liczących od 100 do 500 tys. mieszkańców i posiadających co najmniej jeden uniwersytet (założenia metodologii rankingu) znalazło się pięć polskich miast (Rzeszów - miejsce 48, Białystok 53, Bydgoszcz - 57, Szczecin - 62, Kielce 64). Zwycięzcami były miasta: Luksemburg, Aarhus i Turku (Smart-cities.eu 2020).

Uznanie za najbardziej innowacyjne miasto w Polsce - ranking najbardziej innowacyjnych miast w Polsce edycja 2019 został opracowany przez Forbes. Powstał na podstawie ankiety uwzględniającej ocenę następujących zagadnień związanych z funkcjonowaniem miasta: strategiczny program rozwojowy na kolejne lata; wykorzystanie internetu w komunikacji z mieszkańcami; otwarte i ogólnodostępne sieci wi-fi; technologie mobilne; system informacji przestrzennej; SMS-owy system informowania i ostrzegania mieszkańców. Zwycięzcą został Gdańsk, drugie miejsce zajął Wrocław, a trzecie Poznań (Forbes.pl 2019).

Kolejnym wyznacznikiem smart city w Polsce może być znalezienie się w gronie laureatów konkursu „Human Smart Cities. Inteligentne miasta współtworzone przez mieszkańców", zorganizowanego w 2018 r. przez ówczesne Ministerstwo Inwestycji

4 Ten ranking jest ciekawy z punktu widzenia metodologicznego, ponieważ bierze pod uwagę 140 miast ujętych w różnych, innych rankingach smart cities oraz dostępne informacje na ich stronach internetowych. i Rozwoju. Laureaci to ogółem 25 miast (w tym 2 duże - Kielce i Lublin, 15 średnich Krosno, Mińsk Mazowiecki, Tomaszów Mazowiecki, Kołobrzeg, Kłodzko, Zamość, Ełk, Nowa Ruda, Nakło nad Notecią, Ostróda, Rawicz, Pleszew, Sierpc, Zduńska Wola, Siemianowice Śląskie i 8 miast małych - Żuromin, Siechnice, Kępice, Krynica Zdrój, Zakliczyn, Boguchwała, Podkowa Leśna, Sędziszów), które otrzymały dofinansowanie na realizację projektów z zakresu smart. Wśród obszarów tematycznych, w których zgłaszane były projekty, znalazła się partycypacja społeczna i inteligentne zarządzanie miastem oraz wykorzystanie danych o mieście (Popt.gov.pl 2020) Należy jednak podkreślić, że znalezienie się wśród laureatów konkursu automatycznie nie przesądza jeszcze o wdrożeniu idei smart do zarządzania miastem, a raczej stanowi deklarację i informację, zarówno dla interesariuszy zewnętrznych jak i wewnętrznych, o aspiracjach w tym zakresie.

Certyfikacja według normy ISO $37120-$ obecnie certyfikat posiada: Gdynia, Gdańsk ${ }^{5}$, Kielce, Warszawa i Lublin ${ }^{6}$ - w dalszej części tekstu zostanie ona dokładniej przeanalizowana (Dataforcities.org 2020; Systemanaliz. pl 2020 $)^{7}$.

Ponadto można wskazać jeszcze jeden wyznacznik niezmiernie istotny dla miast smart (szczególnie 3.0) niezależnie od ich wielkości i poziomu rozwoju, a mianowicie angażowanie użytkowników miasta w procesy decyzyjne, z wykorzystaniem nowoczesnych technologii, czyli e-partycypację. Ten wyznacznik staje się kluczowy, wziąwszy pod uwagę doświadczenia pandemii, gdyż dzięki e-partycypacji możliwe było i jest prowadzenie konsultacji i podejmowanie decyzji w duchu governance.

5 Gdańsk był certyfikowany przez Polski Rejestr Statków, dlatego nie jest ujęty w zestawieniu World Council on City Data.

6 Lublin, jako pierwsze miasto, był certyfikowany przez Polski Komitet Normalizacyjny, dlatego nie jest ujęty w zestawieniu World Council on City Data.

7 Stan na 20 lutego $2020 \mathrm{r}$. 


\section{E-partycypacja jako podstawa funkcjonowania smart city}

E-partycypacja, wykorzystywana we wdrażaniu smart city, jest nieodłącznym elementem e-demokracji, czyli tworzenia modelu społeczeństwa, w którym obywatele za pomocą narzędzi ICT biorą aktywny udział w procesach demokratycznych (Gajowniczek 2015). Wprawdzie pojawienie się internetu nie rozwiązało wszystkich problemów związanych z partycypacją ${ }^{8}$, ale rozwój społeczeństwa sieciowego i nowych narzędzi komunikacji dał możliwość dywersyfikowania narzędzi partycypacji, w tym wykorzystania e-partycypacji (zazwyczaj jako „jednego z”, a nie jedynego sposobu partycypacji). Wdrażany w smart city 3.0 proces partycypacji w swojej najbardziej zaawansowanej formie powinien doprowadzić do współuczestniczenia w procesie rozwoju (zgodnie z zapisami prawnymi w Polsce powinien być to rozwój zrównoważony), czyli partnerstwa prowadzącego do współdecydowania, ale i współodpowiedzialności interesariuszy miasta (mówimy wówczas o delegowanym bądź symetrycznym modelu partycypacji ${ }^{9}$ ).

8 Już w 1969 r. została sformułowana przez Sherry R. Arnstein tzw. drabina partycypacji, w której wskazano 8 etapów (szczebli) dochodzenia do realnego współdecydowania przez mieszkańców (obywateli) o sprawach ich (bezpośrednio lub pośrednio) dotyczących. Obecnie klasyczna 8 szczeblowa drabina partycypacji jest rzadko stosowana. Miasta (i szerzej samorządy lokalne) wskazują 4 (a czasem nawet tylko 3) stopnie i natężenia partycypacji: bardzo niską partycypację (tylko w 4-stopniowym ujęciu), znikome, średnie i wysokie natężenie partycypacji. Każdy ze stopni ma przypisane odpowiednie narzędzia partycypacji, dające możliwości zwiększania udziału w procesach decyzyjnych. W praktyce działań samorządowych zauważyć można, że ciągle w partycypacji udział bierze zdecydowana mniejszość mieszkańców, przeważa milcząca większość, nieangażująca się w procesy partycypacji (Jastrzębska i Legutko-Kobus 2015; Hołuj i Legutko-Kobus 2018).

9 Model delegowany zakłada dominujący udział obywateli przy udziale (od znikomego po znaczny) władz publicznych, symetryczny zaś dotyczy sytuacji, w której udział obydwu stron, tj. obywateli i innych interesariuszy miasta oraz władz publicznych,
Chodzi więc o stosowanie takich narzędzi e-partycypacji, żeby użytkownik miasta nie był tylko biernym odbiorcą informacji, ale co najmniej doradcą, a najlepiej partnerem podejmowanych działań prorozwojowych, zmierzających do osiągnięcia ładu zintegrowanego. Smart obywatel miasta powinien więc cechować się wysokimi kompetencjami cyfrowymi, żeby nie tylko umieć korzystać z dostępnej informacji i danych, lecz także przetwarzać je w użyteczny dla siebie sposób (Ilciów 2017, 41).

Natężenie e-partycypacji, podobnie jak natężanie partycypacji, może mieć różny poziom, a jej zaawansowanie i poszczególne etapy nazywane są drabiną e-partycypacji ${ }^{10}$ opierającej się na komunikacji jedno i dwukierunkowej. Najniższe stopnie związane są z komunikacją jednokierunkową - interesariusze miasta mogą pozyskać wiedzę (informacje) lub dostarczyć informacji (narzędzia partycypacji to: strony www oraz ankiety online), a podstawowym założeniem w tym ujęciu jest prawo do pozyskania informacji (możliwie szerokiej, sprofilowanej dla różnych użytkowników miasta), która zamieszczana jest na stronach internetowych prowadzonych przez administrację publiczną.

Osiągnięcie wyższych poziomów drabiny e-partycypacji wymaga przezwyciężenia bariery komunikacyjnej i prowadzenia komunikacji dwukierunkowej, z wykorzystaniem np. forów dyskusyjnych, dedykowanych miejskich platform internetowych do konsultacji społecznych, komentarzy on-line, systemów informacji przestrzennej wykorzystywanych do partycypacji publicznej oraz podejmowania decyzji on-line (Kingston 2002, 4). W rozszerzonej drabinie e-partycypacji zwraca się ponadto uwagę na brak możliwości jednoznacznego zdefiniowania ról uczestników procesu (zachodzi wymienność ról), ponieważ odbiorcy i nadawcy komunikacji mogą pełnić swoje

jest zrównoważony (Olech i Kaźmierczak 2011, 102-109).

10 Drabina e-partycypacji opracowana została w 2002 r. przez Richarda Kingstona z zespołem. 
role zamiennie, różny jest też stopień zaangażowania uczestników procesu partycypacji i różne nastawienie do proponowanych kanałów przepływu informacji (mamy w takim przypadku do czynienia z komunikacją i partycypacją sieciową wykorzystującą wiele powiązań i wiele narzędzi równocześnie). W takim podejściu do partycypacji, dostęp do danych o mieście uznaje się za warunek konieczny, dla natężenia procesu kluczowe zaś znaczenie ma równy dla wszystkich uczestników dostęp do tych danych (Hanzl 2008, 89-9o).

E-partycypacja to narzędzie e-administracji coraz częściej stosowane dla ułatwienia użytkownikom miasta m.in. udziału w procedurach tworzenia dokumentów strategicznych i planistycznych na poziomie lokalnym (czyli dokumentów programowania rozwoju zrównoważonego). Pełni więc równocześnie rolę informacyjną i konsultacyjno-opiniodawczą, wykorzystując komunikację jedno- i dwukierunkową, miasta zaś określane mianem smart budują często specjalistyczne narzędzia (platformy) do partycypacji. Przykładem takiego narzędzia może być platforma IDEA Kielce ${ }^{11}$, opracowana i uruchomiona jako jeden z kluczowych elementów wdrażania smart city. Głównie wykorzystywana jest jako narzędzie konsultacji społecznych (umieszczane są tu ankiety, formularze konsultacyjne dotyczące istotnych spraw dla miasta), przy tym zawiera także inne istotne informacje m.in. o budżecie obywatelskim, certyfikacji miasta zgodnie z normą ISO $37120 \mathrm{w}$ zakresie rozwoju zrównoważonego, dostęp do opracowań i map w ramach Geoportalu oraz informacje nt. koncepcji i założeń strategii Smart City Kielce.

\section{Norma ISO 37120 jako instrument oceny poziomu wdrażania rozwoju zrównoważonego}

Oprócz partycypacji (w tym szczególnie e-partycypacji) wyznacznikiem, który pozwala zaliczyć konkretne smart city do miast

${ }^{11}$ Dostęp do platformy: https://idea.kielce.eu/. wdrażających rozwój zrównoważony, może być system certyfikacji ISO 37120 . Norma została opracowana pod kierownictwem kanadyjskiej organizacji pozarządowej World Council on City Data (WCCD) i jest dostosowana do wszystkich miast, bez względu na wielkość czy zaawansowanie wdrożenia idei smart. Zastosowanie normy pozwala zmierzyć efekty działalności miasta związane z usługami publicznymi i jakością życia w sposób porównywalny i możliwy do zweryfikowania. Norma PN-ISO 37120:2015-03 Zrównoważony rozwój społeczny - wskaźniki ustug miejskich i jakości życia została opublikowana przez Polski Komitet Normalizacyjny w lutym $2017 \mathrm{r}$.

Pomiar rozwoju zrównoważonego miast, z wykorzystaniem tej normy, odbywa się przez analizę maksymalnie 100 wskaźników, z których 46 ma charakter podstawowy, a 54 dodatkowy. Wszystkie wskaźniki zostały podzielone na 17 głównych grup (kategorii) tematycznych, odpowiadających różnym aspektom (i celom) rozwoju zrównoważonego i jakości życia. Są to: edukacja, straż pożarna i reagowanie kryzysowe, bezpieczeństwo, środowisko, gospodarka, finanse, rekreacja, zdrowie, telekomunikacja i innowacja, transport, zarządzanie, energia, mieszkanie i schronienie, odpady stałe, woda, ścieki, urbanistyka (planowanie przestrzenne) (Moduł ISO 37120 2020). Wskaźniki obejmują więc wszystkie kluczowe obszary (łady) rozwoju zrównoważonego, co oznacza, że z ich wykorzystaniem można monitorować jego wdrażanie.

WCCD, z którego certyfikacji korzysta zdecydowana większość miast, zakłada, że mogą one uzyskać 5 poziomów certyfikacji (w zależności od liczby wskaźników raportowanych przez miasto) (WCCD ISO 37120):

- poziom aspirujący - miasto raportuje od 30 do 45 wskaźników podstawowych (ten poziom miała Gdynia w pierwszym okresie certyfikacji 2017 r., obecnie od 2018 r. ma już poziom platynowy);

- poziom brązowy - miasto raportuje od 46 do 59 wskaźników, w tym 46 
wskaźników podstawowych oraz do 13 wskaźników uzupełniających;

- poziom srebrny - miasto raportuje od 60 do 75 wskaźników, w tym 46 wskaźników podstawowych oraz 14-29 wskaźników uzupełniających;

- poziom złoty - miasto raportuje od 76 do 90 wskaźników, w tym 46 wskaźników podstawowych oraz 30-44 wskaźników uzupełniających;

- poziom platynowy - miasto raportuje 91 do 100 wskaźników, w tym 46 wskaźników podstawowych oraz 45-54 wskaźników uzupełniających (obecnie wszystkie trzy polskie miasta certyfikowane przez WCCD mają ten poziom certyfikacji - oprócz wymienionej wcześniej Gdyni także Kielce od 2017 r. oraz Warszawa od 2019 r.).

Gdańsk certyfikowany w 2017 r. przez Polski Rejestr Statków, raportuje 87 wskaźników (w tym wszystkie obowiązkowe). Lublin, którego certyfikację przeprowadził Polski Komitet Normalizacyjny w 2019 r., raportuje 96 wskaźników.

W opinii badaczy (m.in. Salerno-Kochan 2016; McCarney 2015) norma ISO 37120 jest odpowiedzią na postępującą urbanizację i coraz większe zapotrzebowanie na obiektywne dane, na podstawie których mogą być podejmowane decyzje związane z planowaniem rozwoju miast. Ponadto miasta zyskują narzędzie do skutecznego zarządzania usługami publicznymi i oceny ich jakości oraz oceny poziomu i jakości życia. Co istotne, wskaźniki dają także możliwości porównywania się z innymi miastami (benchmarking) oraz określenia dobrych praktyk i uczenia się od siebie nawzajem. W opinii samych miast (Malinowska i Kurkowska 2018) certyfikat ma znaczenie marketingowe i pomaga budować markę terytorialną, stanowi narzędzie do rozmów $\mathrm{z}$ inwestorami oraz jednoznacznie identyfikuje miasto jako smart. Miasta, które wdrożyły ISO 37120, podkreślają także spodziewane długofalowe korzyści, takie jak zaliczenie do grona liderów smart cities, szczególnie w sytuacji, gdy tych miast w Polsce jest tylko kilka. Ponadto wskaźniki to dane (otwarte), które mogą być wykorzystywane przez różnych interesariuszy.

Z punktu widzenia wdrożenia rozwoju zrównoważanego ISO 37120 daje następujące korzyści:

- rozwój traktuje holistycznie jako zapewnienie wysokiej jakości życia, na którą składa się wiele elementów (monitorowanych przez wskaźniki przypisane do 17 obszarów tematycznych);

- pozwala na tematyczne uporządkowanie danych (często bardzo szczegółowych i trudnych do interpretacji bez wskazanych powiązań), co ułatwia korzystanie $\mathrm{z}$ nich różnym grupom interesariuszy;

- jest narzędziem prowadzenia polityki opartej na dowodach (evidence-based policy) dostępnych w tym samym zakresie dla wszystkich grup interesariuszy, co może ułatwiać wdrożenie governance jako zasady lokalnej polityki rozwoju zrównoważonego;

- koncentracja tematyczna i podejście dynamiczne do wskaźników pozwalają lepiej diagnozować pojawiające się problemy i w razie potrzeby szybciej reagować na pojawiające się wyzwania rozwojowe;

- jednolity system wskaźników dla wszystkich miast pozwala także na poszukiwanie wzorców i liderów wdrażających dobre praktyki w poszczególnych obszarach tematycznych, co jest niezwykle istotne z punktu widzenia różnych, przyjętych obecnie priorytetów i celów rozwojowych poszczególnych miast (Pdbc.gov.pl 2020).

\section{Podsumowanie}

W Polsce 6o\% ludności żyje w miastach, w tym najwięcej w wielkich miastach (powyżej 200 tys. mieszkańców). Ponieważ gęstość zaludnienia w miastach jest duża, to zapewnienie transportu publicznego, mieszkań, prądu, wody i kanalizacji jest tańsze i mniej obciążające dla środowiska niż dostarczanie tych samych usług publicznych w rozproszonej zabudowie wiejskiej 
(UN 2014). Równocześnie to w miastach kumulują się problemy rozwojowe, w tym społeczne i środowiskowe, a wdrażanie rozwoju zrównoważonego staje się wyzwaniem strategicznym. Jak starano się wykazać w artykule, współcześni liderzy smart cities mogą być także liderami we wdrażaniu rozwoju zrównoważonego. Dzieje się tak, ponieważ współczesne miasta chcą stawać się coraz lepszymi miejscami do życia i umożliwiać realizację ambicji rozwojowych swoim mieszkańcom (a nawet szerzej użytkownikom, w tym turystom czy inwestorom). Koncepcja smart city wychodzi naprzeciw tym oczekiwaniom, wprzęgając nowoczesne technologie do działań innowacyjnych w każdym obszarze funkcjonowania miasta - w ten sposób umożliwiając także wdrażanie rozwoju zrównoważonego do lokalnej polityki rozwoju. Polskie miasta nie należą do europejskich czy światowych liderów smart cities, nie wdrażają kompleksowych rozwiązań z tego zakresu, koncentrując się na poszczególnych elementach, a nie całościowym procesie. Należy jednak podkreślić, że polskie smart cities aspirujące do 3.0, starają się innowacyjnie zwiększyć zaangażowanie mieszkańców w kreowanie polityki rozwoju miasta, wykorzystując narzędzia cyfrowe do współdecydowania, np. systemy pozwalające na dokonywanie obywatelskich interwencji, rozwiązania typu Living Lab, dostępność usług on-line oraz informatyzację miasta i otwarte dane (Eecpoland. pl 2018). Zarówno miasta, jak i ich mieszkańcy są zainteresowani obiektywną oceną oraz porównaniem jakości i poziomu życia oraz szerzej wdrażaniem rozwoju zrównoważonego, a jednym $\mathrm{z}$ narzędzi certyfikowania, ale i wdrażania w smart city rozwoju zrównoważonego, jest norma ISO 37120. Stanowi ona nie tylko podstawę oceny, lecz także dostarcza niezbędnych informacji (danych), które mogą być w różny sposób wykorzystywane przez interesariuszy miasta, np. do społecznego zarządzania miastem (Szumowski 2012, 77).

W Polsce norma ISO 37120 Zrównoważony rozwój społeczny - wskaźniki ustug miejskich i jakości życia nie jest zbyt popularna. Miasta, które ją wdrożyły (Gdynia, Gdańsk, Kielce, Lublin, Warszawa), chcą wyraźnie zaakcentować, że wdrażanie koncepcji smart łączą z dążeniem do wysokiej jakości życia, osiąganej dzięki konsekwentnej implementacji rozwoju zrównoważonego. Ponadto miasta te rozumieją znaczenie współpracy na rzecz rozwoju i często są liderami wdrożenia smart city także w innych obszarach (np. e-partycypacji - jak Kielce, Gdańsk czy Warszawa). Wydaje się, że wdrażanie koncepcji smart city - bardzo popularne i nośne w ostatnich latach - może przyczyniać się do szybszego i skuteczniejszego osiągnięcia rozwoju zrównoważanego na obszarach miast, nie tylko dzięki coraz doskonalszym technologiom, lecz przede wszystkim dzięki zwiększeniu zaangażowania społecznego (wykorzystującego nowoczesne technologie do współdecydowania) oraz dążeniu miast do pozyskiwania i udostępniania coraz lepszych i dokładniejszych danych związanych z różnymi aspektami rozwoju zrównoważonego (przydatnymi więc dla różnych grup interesariuszy).

\section{Bibliografia}

Berreta, Ilaria. 2018. "The Social Effect of Eco-Innovations in Italian Smart Cities." Cities 72: 115-121.

Betterworldsolutions.eu. 2020. Top 10 Eco Cities. Accessed 24.01.2020. https://www.betterworldsolutions.eu/top-10-eco-cities/.

Borys, Tadeusz. 2011. „Zrównoważony rozwój - jak rozpoznać ład zintegrowany." Problemy Ekorozжоји 6(2): 75-81.

Caragliu, Andrea, Chiara Del Bo, and Peter Nijkamp. 2011. "Smart cities in Europe." Journal of Urban Technology 18(2): 65-82.

Chomiak-Orsa, Iwona, i Paulina Szurant. 2015. „W kierunku smart city - perspektywy polskie i światowe." Informatyka Ekonomiczna 3(37): 38-47. https://doi.org/10.15611/ie.2015.3.03.

Cohen, Boyd. 2015. "The 3 Generations of Smart Cities. Inside the Development of the Technology Driven City." Accessed 25.01.2020. https://www.fastcompany.com/3047795/ the-3-generations-of-smart-cities. 
Dataforcities.org. 2020. WCCD ISO 37120. Accessed 5.02.2020. http://open.dataforcities.org/.

Dominiak, Bartosz. 2016. „Inteligentne miasta trzeciej generacji." Dostęp 2.03.2020. http://smartcityforum.pl/artykul/inteligent ne-miasta-trzeciej-generacji.

Dominik, Bartosz. 2020. „Smart city, czyli miasta coraz bardziej inteligentne." Dostęp 6.08.2020. https://www.przestrzen-miejska.pl/artykul/ smart-city-czyli-miasta-coraz-bardziej-inteligentne.

Eco-miasto.pl. 2020. Czym jest ECO-MIASTO. Dostęp 26.01.2020. http://www.eco-miasto. pl/o-projekcie/czym-jest-eco-miasto/.

Eden Strategy Institute and ONG\&ONG Pte Ltd. 2018. 50 Smart City Government. Accessed 28.01.2020. https://static1.squarespace.com/ static/5b3c517fec4eb767a04e73ff/t/5b513c57aa 4a99f62d168e60/1532050650562/Eden-OXD_ Top+50+Smart+City+Governments.pdf.

Eecpoland.eu. 2018. Europejski Kongres Gospodarczy. Prezentacja: „Dobre praktyki w smart cities w Polsce." Dostęp 1.03.2020. www.eecpoland.eu.

Forbes.pl. 2019. Jak wymyślić nowe miasto. Najbardziej innowacyjne miasta. Dostęp 28.01.2020. https://www.forbes.pl/gospodarka/ranking-najbardziej-innowacyjne-miasta-x-kongres-regionow-2019/ eh55s9y.

Gajowniczek, Tomasz. 2015. „Elektroniczna demokracja - istota pojęcia i problemy definicyjne." W Demokracja a wybory. Wspótczesne dylematy i wyzwania, red. Waldemar Tomaszewski, Diana Mościcka, i Andrzej Jurkun. Olsztyn: Instytut Nauk Politycznych, UWM w Olsztynie.

Gazeta.pl. 2018. Najbardziej zielone miasta na świecie. Dostęp 26.01.2020. https://metrowarszawa. gazeta.pl/metrowarszawa/56,141635,23354730 ,warszawa-lepsza-niz-paryz-tokio-i-nowy-jorkpolskie-miasto.html.

Gori, Paula, Pier Luigi Parcu, and Maria Stasi. 2015. "Smart Cities and Sharing Economy." Robert Schuman Centre for Advanced Studies. Research Paper No. RSCAS 2015/96. http://dx.doi.org/10.2139/ ssrn. 2706603.

Hajduk, Sławomira. 2020. „Modele smart city a zarządzanie przestrzenne miast." Gospodarka Narodowa 2(302): 123-139. http://dx.doi. org/10.33119/GN/120626.
Hanzl, Małgorzata. 2008. „Technologie informacyjne jako narzędzie udziału społecznego w kształtowaniu przestrzeni." Roczniki Geomatyki 6(3): 87-99. Höjer, Mattias, and Josefin Wangel. 2014. "Smart Sustainable Cities. Definition and Challenges." Accessed 2.03.2020. https://www.researchgate.net/ publication/265594929_Smart_Sustainable_Cities_Definition_and_Challenges.

Hołuj, Dominika, i Paulina Legutko-Kobus. 2018. „Partycypacja jako element rewitalizacji (przykłady miast $\mathrm{z}$ województwa małopolskiego i mazowieckiego)." Studia Ekonomiczne. Zeszyty Naukowe Uniwersytetu Ekonomicznego w Katowicach 365: 93-119.

Hulicka, Anna. 2015. „Miasto zielone - miasto zrównoważone. Sposoby kształtowania miejskich terenów zieleni w nawiązaniu do idei green city." Prace Geograficzne 141: 73-85. https://doi.org/10 .4467/20833113PG.15.010.4062.

MIiR (Ministerstwo Inwestycji i Rozwoju). 2019. Human Smart City. Przewodnik dla samorzadów. 2019. Dostęp 5.03.2020. https:// www.popt.gov.pl/strony/wiadomosci/ human-smart-city-przewodnik-dla-samorzadow/. IESE.edu. 2019. IESE Cities in Motion Index. Accessed 10.02.2020. https://media.iese.edu/research/ pdfs/ST-0509-E.pdf.

Ilciów, Adam. 2017. „W poszukiwaniu smart obywatela. Analiza realizacji koncepcji smart city w Polsce." Acta Politica Polonica 4(42): 33-45.

Jastrzębska, Ewa, i Paulina Legutko-Kobus. 2015. „Partycypacja w obszarach funkcjonalnych (przykład Metropolii Poznań)." W Problemy zarzadzania $w$ jednostkach samorzadu terytorialnego, red. Beata Banachowicz, Katarzyna Wojtaszczyk, i Małgorzata Żak-Skwierczyńska, 236-255. Łódź: Katedra Zarządzania Miastem i Regionem Wydział Zarządzania Uniwersytetu Łódzkiego.

Kingston, Richard. 2002. "The role of e-government of public participation in the planning process." Accessed 5.03.2020. https://www.researchgate. net/publication/228363234_The_role_of_e-government_and_public_participation_in_the_planning_process/link/547e20220cf2d2200ede9568/ download.

Lewandowska, Aleksandra. 2014. „Koncepcja miasta zrównoważonego i próby jej wdrożenia w europejskiej przestrzeni osadniczej.” W Miasto - nauka, 
gospodarka, sztuka, red. Katarzyna Sadowy, 90-98. Warszawa: Fundacja Architektury.

Malinowska, Ewa, i Anna Kurkowska. 2018. „Norma ISO 37120 narzędziem pomiaru idei zrównoważonego rozwoju miast." Zeszyty Naukowe Politechniki Ślaskiej. Organizacja i Zarzadzanie 18: 363-382.

McCarney, Patricia. 2015. "The evolution of global city indicators and ISO 37120: The first international standard on city indicators." Statistical Journal of the IAOS 31(1): 103-110. https://doi. org/10.3233/SJI-150874.

Olech, Anna, i Tomasz Kaźmierczak. 2011. „Modele partycypacji publicznej.” W Partycypacja publiczna. O uczestnictwie obywateli w życiu wspólnoty lokalnej, red. Anna Olech, 102-109. Warszawa: ISP.

Papuziński, Andrzej. 2014. „Zrównoważony rozwój w kontekście teorii sprawiedliwości międzygeneracyjnej. Próba konkretyzacji problemu." Studies in Global Ethics and Global Education 2:12-27. https://doi.org/10.5604/23920890.1134202.

Pcbc.gov.pl. 2020. Korzyści, jakie daje norma ISO 37120. Dostęp 16.02.2020. https://www.pcbc.gov. pl/pl/uslugi/certyfikacja-systemow-zarzadzania/ pn-iso-37120.

Pichlak, Magdalena. 2018. „Inteligentne miasta w Polsce - rzeczywistość, czy utopia?” Zeszyty Naukowe Politechniki Ślaskiej. Organizacja i Zarzadzanie 127: 191-206.

Popt.gov.pl. 2020. „Konkurs «HUMAN SMART CITIES. Inteligentne miasta wspóttworzone przez mieszkańców»." Dostęp 26.01.2020. https://www. popt.gov.pl/strony/o-programie/wydarzenia/ konkurs-dla-samorzadow-human-smart-cities-inteligentne-miasta-wspoltworzone-przez-mieszkancow/.

Salerno-Kochan, Marek. 2016. „Norma ISO 37120. Próba oceny jakości życia w miastach." W Wybrane aspekty zarzadzania jakościa, red. Marek Salerno-Kochan, 251-257. Kraków: Polskie Towarzystwo Towaroznawcze.

Smart-cities.eu. 2020. European smart cities. Accessed 16.01.2020. http://www.smart-cities.eu/ ranking.html.

Sobol, Agnieszka. 2017. „Inteligentne miasta versus zrównoważone miasta." Studia Ekonomiczne. Zeszyty Naukowe Uniwersytetu Ekonomicznego w Katowicach 320: 75-86.

Systemanaliz.pl. 2020. Modut ISO 37120. Dostęp 11.02.2020. https://www.systemanaliz.pl/ iso-37120.

Szumowski, Witold. 2012. „Koncepcja Good Governance w doskonaleniu systemu zarządzania urzędu administracji samorządowej." Nauki o Zarzadzaпіи 4(13): 75-84.

UN. 2014. World Urbanization Prospects. New York: $\mathrm{UN}$.

Węcławowicz-Bilska, Elżbieta. 2012. „Miasto przyszłości - tendencje, koncepcje, realizacje.” Czasopismo Techniczne 1: 323-342. 